DOI: http://dx.doi.org/10.23925/2176-2767.2020v69p90-136

Recebido em: 24/06/2020 Aprovado em: 10/08/2020

\title{
AR'TIGO
}

\section{VISÕES SOBRE O HUMANO: \\ A FRONTEIRA-SERTÃO DO BRASIL MERIDIONAL \\ $(1889-1905)^{1}$}

\author{
VIEWS ON THE HUMAN: \\ THE BACKLANDS OF SOUTHERN BRAZIL \\ (1889-1905)
}

BRUNO PEREIRA DE LIMA ARANHA²

\begin{abstract}
RESUMO
Este artigo consiste numa proposta de análise de relatos decorrentes das expedições brasileiras que se dirigiram à fronteira com a Argentina entre 1889 e 1905, onde hoje se localiza a província de Misiones (Argentina) e as regiões sudoeste do Paraná e oeste de Santa Catarina e Rio Grande do Sul, no lado brasileiro. Nossa análise busca ampliar a ideia de fronteira atrelada a um marco delimitador para pensá-la dentro de uma experiência histórica de fronteira móvel, onde existe uma borderland, idealizada pelos viajantes como um sertão a ser ocupado formalmente pelo Estado. Com isto, percebemos que o olhar manifestado sobre as populações sertanejas era permeado por diversas nuances, sobretudo, por se tratar de um espaço transnacional onde ainda não existia uma fronteira demarcada de fato.
\end{abstract}

PALAVRAS-CHAVE: Fronteira Brasil-Argentina; Borderland; Sertão; Sertanejo; Caboclo.

\begin{abstract}
This article consists of a proposal for the analysis of reports resulting from Brazilian expeditions to the border with Argentina between 1889 and 1905, where today is the province of Misiones (Argentina) and the southwestern regions of Paraná and west region of Santa Catarina and Rio Grande do Sul, on the Brazilian side. Our analysis seeks to expand the idea of frontier as a demarcation line to see it as a borderland, idealized by travelers as a sertão to be formally occupied by the State. We realized that
\end{abstract}

1 Este artigo é parte da minha tese de doutorado, intitulada Entre Sertões e Desiertos: Viajantes brasileiros e argentinos na fronteira (1882-1905), defendida no ano de 2020 no Programa de Pós Graduação em História da Universidade Federal do Estado do Rio de Janeiro (UNIRIO).

2 Doutor em História pela Universidade Federal do Estado do Rio de Janeiro (UNIRIO) https://orcid.org/0000-0003-4814-3142 
the manifested comprehension of the sertanejos of this inland region was crossed by several nuances, mainly related to the fact that this transnational space did not have a real demarcated border yet.

KEYWORDS: Brazil-Argentina border; Borderland; Sertão; Sertanejo; Caboclo.

\section{A Fronteira-Sertão}

Quando paramos para refletir acerca dos significados para o conceito de fronteira, normalmente, a primeira associação diz respeito a uma linha que demarca um limite entre duas nações. A nossa preocupação, entretanto, vai mais além. No presente artigo, buscamos abstrair o seu sentido estritamente demarcatório para atentar-nos para os movimentos das frentes de ocupação humana dentro do espaço que será aqui analisado.

A ideia de uma fronteira em movimento ganhou bastante sentido dentro do espaço americano, sobretudo durante o século XIX, período este que marcou a legitimação das novas nações herdeiras da colonização europeia, as quais necessitavam justificar suas respectivas expansões para o interior do continente. Em 1893, o historiador estadunidense Frederick Jackson Turner (2004) escreveu um paper intitulado "O significado da fronteira na História Americana". Neste trabalho, a história dos Estados Unidos é contada a partir de uma sucessão de avanços, iniciada na costa atlântica a partir das antigas 13 Colônias Inglesas. Tratava-se de uma fronteira em movimento que rumou para o oeste até alcançar a costa do Pacífico.

A sua teoria, carregada pelos preceitos evolucionistas característicos do século XIX, foi alvo de intensas críticas durante o século XX, sobretudo, porque salientava apenas o avanço da população 
branca, os chamados pioneers. Os seus revisores, entretanto, abriram possibilidades para análises que ampliaram o leque dos movimentos fronteiriços, analisando-os dentro da dinâmica de uma borderland, a qual se entende como zona de contato e fluxo dos mais diversos. Sendo assim, foram contemplados novos olhares em relação à fronteira com os antigos domínios espanhóis na América do Norte, além de abordar também os contatos travados com diversas confederações indígenas (BOLTON, 1996) (LIMERICK, 1987). Jeremy Aldeman e Stephen Aron (1999, p. 817), citando o nordeste brasileiro e a região do Prata, abrem ainda as possibilidades de pensar outras borderlands dentro do espaço americano como um todo.

Cada projeto nacional americano teve suas peculiaridades. Para o caso brasileiro, o contexto do avanço de suas fronteiras sobre os espaços internos projetados como parte da nação - conjuntura esta que provinha desde a Era Colonial- não pode ser analisada sem um devido olhar para a problemática da ocupação do sertão, ou, de maneira mais assertiva, sertões, no plural, já que eles estavam presentes dentro de todo o espaço pretendido como parte da nação brasileira.

É possível afirmar que a palavra sertão seja uma corruptela de desertão, palavra que já era utilizada pelos portugueses na Idade Média para designar os espaços interiores de Portugal. O conceito foi ganhando amplitude na medida em que foi ocorrendo a expansão ultramarina pela África, sobretudo, quando os lusitanos travaram contato com o deserto do Saara. A palavrão sertão aparece na carta de Pero Vaz de Caminha, cuja grafia original é sertaão, para designar os lugares ocultos afastados da costa (ANTONIO FILHO, 2011, p. 85). Na medida em que foi 
avançando a colonização portuguesa, o conceito de sertão passou a fazer mais sentido dentro do espaço americano, passando a integrar o vocabulário nacional até nossos dias. Durante o período colonial foi bastante comum a utilização da nomenclatura "boca do sertão" para designar as vilas construídas no interior que demarcavam a fronteira da colonização lusitana (MAIA, 2014, p. 2).

Com o início da vida independente da nação brasileira, o conceito de boca do sertão ganhou ainda mais peso, afinal, a ocupação e a domesticação dos sertões delineou totalmente a construção da nação brasileira durante todo o século XIX. Tanto a elite imperial, quanto a elite republicana, oriundas da costa atlântica, lançou as suas respectivas projeções sobre os sertões, presentes de norte a sul dentro do espaço pretendido como nacional, no sentido de projetá-los como espaços desertos que necessitavam de uma presença efetiva do Estado.

Para compreendermos a importância do sertão dentro do contexto da construção da nação brasileira é necessário entender a sua polissemia e como ele foi projetado pelos agentes ligados ao Estado no sentido de legitimar um lugar deserto a ser conquistado. Para estes, não se tratava de uma localidade, um bioma ou uma região plenamente definida, tratava-se de uma projeção emanada por eles próprios. Para ilustrar este argumento, cabe ressaltar que os habitantes do sertão não se enxergavam eles mesmos como sertanejos. Quem assim os denominava eram os forasteiros oriundos do litoral que julgavam a si próprios como portadores da civilização, em detrimento do outro sertanejo, considerado por eles como parte da paisagem atrelada ao atraso e à barbárie. 
Vemos que existia uma apropriação simbólica do vasto interior como um lugar composto por índios ferozes e por uma população degenerada pela mestiçagem. Conforme aponta o geógrafo Antonio Carlos Robert Moraes (2002-2003), existia toda uma tônica de construção de um "outro geográfico", relacionado tanto ao espaço, como às pessoas que aí viviam. Nísia Trindade Lima (1997) associa esse distanciamento à maneira como os intelectuais enxergavam os caminhos para que o Brasil pudesse alcançar a modernidade. Tratava-se de uma via que projetava um sertão atrasado a ser dominado pelo desenvolvimento oriundo da costa atlântica, onde os ditames civilizatórios já se faziam presentes.

Esse distanciamento não significava exatamente uma separação, já que o outro deveria ser conquistado, civilizado e integrado ao corpo da nação. Conforme a concepção ideológica destes agentes externos, a projeção do sertão como um lugar deserto, clamava pela presença efetiva do Estado. Vemos, portanto, que o sertão era imaginado e projetado pela intelectualidade política dos centros urbanos do litoral que se julgava herdeira da civilização europeia. Não se tratava, entretanto, de uma mera reprodução de uma matriz europeia dentro do espaço americano, existiam nuances que projetavam o sertão, ora de maneira positiva, ora por um viés negativo, ainda que a sua integração ao corpo da nação unificasse ambas as visões.

Resulta factível apontarmos para uma ideia de um Brasil-Sertão idealizado pelo pensamento social brasileiro do século XIX. Os debates a respeito do sertão o colocavam como ingrediente central na construção 
da nacionalidade ${ }^{3}$. O Brasil era um grande sertão porque o debate não girava em torno de algum bioma ou alguma área geográfica específica, todo o espaço interior da nação estava envolto dentro da questão sertaneja. As projeções poderiam se direcionar para o oeste paulista ${ }^{4}$, para o sul do país ou para a região nordeste ${ }^{5}$, bastava se afastar um pouco da costa para considerar uma determinada área como sertão.

Ao analisarmos a conjuntura da construção da nacionalidade brasileira, nos deparamos com as questões relacionadas ao sertão e ao avanço da fronteira. Faz-se necessário, portanto, unificar ambos os conceitos, afinal, sertão é fronteira e vice-versa. Podemos apontar que o problema do domínio da fronteira-sertão resultar ser fulcral para compreendermos o processo da formação da nação brasileira, já que se trata de uma experiência histórica de fronteira móvel.

Tal processo foi dotado de particularidades em um determinado contexto geográfico onde tivemos a ocorrência de um choque com outro movimento de fronteira oriundo de um projeto nacional rival dentro do espaço americano. Ao analisarmos o movimento de ocupação dos sertões do Brasil Meridional, resulta impossível dissociá-lo do movimento argentino de ocupação dos espaços projetados por eles próprios como “desiertos". Na Argentina novecentista a afirmação da

\footnotetext{
3 Citamos aqui duas visões antagônicas sobre este processo: o Visconde do Uruguai considerava o sertão como um foco de barbárie, lugar onde os valores da civilização ainda não haviam chegado (MÄDER, 2006, p. 126), enquanto que Sílvio Romero (1888, p. 355) acreditava que o sertão seria onde a nacionalidade brasileira seria forjada de fato através da miscigenação entre o europeu, o indígena e o africano.

4 A historiadora estadunidense Alida Metcalf (1992) realizou um interessante estudo sobre o avanço de fronteira dos bandeirantes paulistas que partiram de Santana do Parnaíba em direção ao oeste.

${ }^{5}$ Foi somente a partir de 1902, com a publicação de Os Sertôes, de Euclides da Cunha, que foi sendo cristalizada a ideia de sertão atrelada às regiões semiáridas do nordeste.
} 
nacionalidade estava atrelada à conjuntura da domesticação do desierto. Tal pensamento permeava a mentalidade da elite política deste período. O conhecido lema de Juan Bautista Alberdi, "gobernar es poblar" gerava uma demanda por projetar um grande desierto a ser ocupado pelo Estado (ALBERDI, s/d, p. 5). No mesmo sentido, para Domingo Faustino Sarmiento (2007, p. 29): "El mal que aqueja a la República Argentina es la extensión: el desierto la rodea por todas partes (...)”.

O histórico de embates entre luso-brasileiros e castelhanos na região do Prata foi bastante intenso durante a Era Colonial. No entanto, o espaço a ser aqui analisado abarca uma área pouco percorrida pelos colonizadores europeus. A região compreendida entre a atual província de Misiones, no nordeste argentino, o sudoeste paranaense, o oeste de Santa Catarina e o noroeste do Rio Grande do Sul era considerado como um vasto sertão a ser ocupado, sobretudo para fazer frente à nação vizinha que também almejava o controle deste território, considerado como um desierto. Ali não existia uma fronteira demarcada, tratava-se de um espaço litigioso, disputado pelos dois projetos nacionais, que teve sua primeira resolução no ano de 1895 através do Tratado de Palmas ${ }^{6}$. Ainda assim, era apenas o início das movimentações das frentes de ocupação provenientes do Rio de Janeiro, Curitiba e Buenos Aires.

As projeções como um todo, de ambos os projetos nacionais, dão margem para analisarmos a região fronteiriça entre Brasil e Argentina sob a ótica de um espaço, todavia, indefinido, uma borderland dotada de uma diversidade de movimentos de fronteira.

6 O Tratado foi assinado mediante arbitragem internacional sob o auspício do presidente dos Estados Unidos, Stephan Grover Cleveland, que arbitrou em favor do Brasil, estabelecendo assim a linha de fronteira que perdura até hoje. 
As fontes desta investigação consistem nos relatos escritos por cinco viajantes brasileiros que se dirigiram para essa fronteira. Três deles eram militares, os quais empreenderam uma rota terrestre, justamente com o objetivo de para caminhos para integrar a fronteira-sertão. Já os dois viajantes civis, optaram pela via já consolidada que navegava o Oceano Atlântico e o rio Paraná, sendo a rota fluvial toda em território $\operatorname{argentino}^{7}$. Os relatos são resultados das expedições que ocorreram entre 1889 e 1905.

Figura 1: Mapa das rotas percorridas pelos viajantes brasileiros

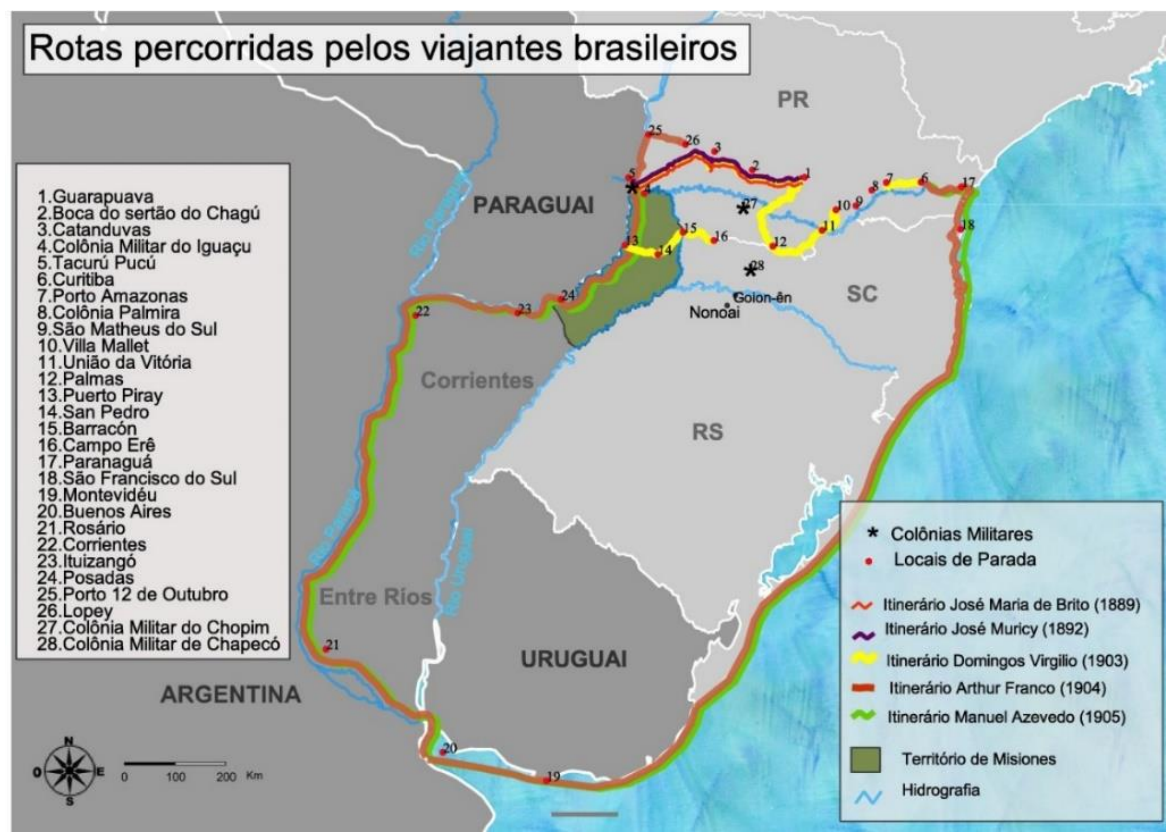

Fonte: (ARANHA, 2020, p. 27)

${ }^{7}$ Essa rota era a principal via de conexão entre o Rio de Janeiro e a província do Mato Grosso. Ela foi bastante utilizada pelo exército imperial durante a Guerra da Tríplice Aliança (1864-1870). 
A análise destes relatos demanda uma necessidade de acoplarmos os estudos pós-coloniais do historiador anglo-australiano Paul Carter (1987). Ao analisar as entrelinhas desse tipo de fonte, o autor busca empreender a desconstrução desses relatos oficiais no sentido de apresentar uma Spatial History, onde seja possível a detecção de uma diversidade de movimentos de fronteira, não ficando assim restrito apenas ao avanço do poder estatal, mas também às dinâmicas de resistência das sociedades locais ante a chegada do agente estrangeiro.

\section{O sertanejo do Brasil Meridional: caboclos, caipiras e gaúchos}

O paranaense Domingos Nascimento ${ }^{8}$, autor de um dos relatos, atentou para a necessidade de o Estado brasileiro deixar de lavar "os pés nas margens do Atlântico" (NASCIMENTO, 1903, p. 215) para direcionar o seu olhar em direção ao seu vasto sertão. Para ele, era na fronteira-sertão, distanciando-se do seu referencial europeu, que a autêntica nacionalidade brasileira seria legitimada de fato. Nesse sentido, o Brasil deveria deixar de ser voltado apenas para o Atlântico e olhar para o seu próprio espaço interior. Seu discurso encontra similaridades

8 Domingos Virgílio do Nascimento (1863-1915) foi figura ativa dentro da elite intelectual de Curitiba. Para além de sua atuação como militar, foi detentor de uma vasta produção bibliográfica, tendo publicado vários livros e poemas, além de ter sido membro da Academia Paranaense de Letras. Fundou ainda o jornal Folha Nova em 1893 com o intuito de defender os ideais republicanos. Também teve uma trajetória política, tendo sido eleito deputado estadual por dois mandatos entre 1893 e 1897 (LORENZETTI, 2009, p. 19; LEMOS, 2019, pp. 81-82). Em 1903, foi designado a participar de uma expedição militar, que saiu de Curitiba e se dirigiu para oeste pela via terrestre, cujo objetivo era o de inspecionar as colônias militares de Iguaçu, Chopim e Chapecó. Nascimento transformou o seu diário de viagem em livro, o qual foi vencedor de um concurso dentro do marco das comemorações do aniversário dos 50 anos da emancipação do Paraná. 
com o que era emanado pelo seu contemporâneo Silvio Romero, o qual acreditava que a fronteira-sertão era o lugar da formação do autêntico povo brasileiro, era nesse ambiente que as leis científicas agiriam em prol da formação de uma sociedade plenamente nacional, diferente das "raças" progenitoras - europeia, indígena e africana - que se mesclariam nesse novo contexto geográfico (ROMERO, 1888, p. 355) (SCHNEIDER, 2019, p. 46).

As expedições que partiram do litoral brasileiro se depararam com uma população sertaneja, a qual, embora fosse vista por um olhar depreciativo que a colocaa numa condição de inferioridade, era também idealizada como parte da nação projetada por estes agentes ligados ao Estado.

O sertanejo não poderia ser categorizado sob uma condição étnica, ele poderia ser um mestiço, ter origem africana ${ }^{9}$, indígena, ser associado ao gaúcho do interior ou até mesmo ser um branco acaipiradoacaboclado. Resulta necessário ainda aclarar o contexto da mentalidade vigente dentro da conjuntura científico-determinista do século XIX, no sentido de demarcar a influência que o meio exercia sobre o homem. Nesse sentido, o ambiente da fronteira-sertão naturalmente transformaria o seu habitante em sertanejo.

$\mathrm{Na}$ medida em que Domingos Nascimento partiu de Curitiba e se deslocou para o oeste, foi se distanciando de sua referência civilizatória, passando a realizar suas projeções sobre um espaço que lhe era completamente desconhecido. Estando a pouco mais de 100 quilômetros

\footnotetext{
${ }^{9}$ Daronco (2018, pp. 265-266) aponta que negros alforriados se acaboclaram nas matas do oeste do Rio Grande do Sul. O reconhecimento de áreas quilombolas na região é uma decorrência direta da ocupação desses espaços por esses afro-brasileiros.
} 
da capital paranaense, em Colônia Palmira ${ }^{10}$ - recém-fundada dentro do contexto do fomento à imigração europeia para o Paraná - mesmo tendo encontrado aí uma população de origem polonesa, projetou o local como um sertão que estava "aclimatando" os seus habitantes e os transformando em sertanejos. Dentro do contexto da dinâmica de exploração da erva-mate nas margens do rio Iguaçu, não existia diferenças significativas entre o polonês e o caboclo brasileiro que habitava este espaço antes da chegada da imigração europeia:

A exportação da herva-matte em rama é feita em grande escala, sendo trabalhada por nacionaes e extrangeiros.

O colono, vindo das regiões do norte da Europa, não affeito aos sertões, deshabituado aos cortes, julgando-se sem meios de mercadejar suas lavouras, adquiridas a custa de enormes sacrifícios, teve necessidade de as abandonar em breve e seguir a industria extractiva dos hervaes, como o caboclo. Hoje não se distingue este daquelle, a não ser pelas entonações do idioma pátrio (NASCIMENTO, 1903, p. 12).

Dentro do conceito geral de sertanejo, a categoria de caboclo é bastante recorrente nos relatos das expedições brasileiras que se dirigiram para a fronteira sul. A etimologia da palavra remete à língua tupi, kari'boka significa "procedente do branco". Entre os indígenas era atribuída essa classificação para designar os mestiços. Com o tempo, a palavra foi sendo disseminada para designar qualquer indivíduo miscigenado.

Todavia, são raros os estudos a respeito das populações mestiças da fronteira sul-brasileira. Ricardo Abramovay (1981, pp. 38-41) foi um dos poucos que se debruçaram sobre o tema. Concentrando sua análise

\footnotetext{
10 Localiza-se às margens do rio Iguaçu, a 20 quilômetros de São João do Triunfo,
} município o qual pertence atualmente. 
no sudoeste paranaense, sua pesquisa mostra que os caboclos eram remanescentes de antigas ocupações luso-brasileiras e fruto da mescla com indígenas e descendentes de escravos. Não possuíam a noção de título de propriedade, tampouco realizavam uma apropriação da terra para uma lógica mercantil. Eram nômades ou seminômades que viviam de maneira autônoma, totalmente alheia à influência do Estado. Por viverem em uma região onde a erva-mate era abundante, praticavam o extrativismo desse artigo para poder trocar por alguns mantimentos.

O conceito de caboclo acaba por ser correlato ao de caipira ${ }^{11}$, que era outra maneira de atribuir significado ao sertanejo. Nascimento, ao descrever os habitantes das margens do Iguaçu, na altura da desembocadura do rio Negro, distante 175 quilômetros de Curitiba, utilizou essa nomenclatura: "E lá na curva do rio, e lá pelas ribanceiras, a esguia canoa de pesca [...] do caipira que habita as margens, sulcando as aguas convulsas, rio acima, rio abaixo [...]" (NASCIMENTO, 1903, p. 15).

O militar José Maria de Brito ${ }^{12}$, único dos viajantes que fixou residência na fronteira, não por acaso, se autodeclarou como um "acaipirado" após uma vivência de tantos anos no sertão. "[...] nós os caipiras e sertanejos do oeste paranaense [...]” (BRITO, 2005, p. 90).

\footnotetext{
${ }^{11}$ Do tupi kai'pira, que significa cortador de mato (FERREIRA, 1986. p. 314).

12 José Maria de Brito (1851-1946), natural do estado do Piauí, se transladou para o Rio de Janeiro para estudar na Escola Militar da Praia Vermelha. Foi transferido para Guarapuava, no centro-oeste paranaense, onde atuou como sargento na Comissão Estratégica de Guarapuava, criada em 1888 pelo Ministério da Guerra do Império com a finalidade de ocupar a região de fronteira com a Argentina. Essa Comissão foi responsável pela fundação da Colônia Militar do Iguaçu em 1889, localizada na fronteira com a Argentina e com o Paraguai. O seu relato é uma descrição da expedição realizada por esta comissão.
} 
Antonio Candido (2001) definiu o modo de vida caipira como uma herança do cruzamento entre os colonizadores portugueses da era do bandeirismo e as populações indígenas do interior do espaço definido por ele como Paulistânia, região que compreendia os atuais estados de São Paulo, Goiás, Mato Grosso do Sul, Mato Grosso, Minas Gerais e Paraná. Não foi por acaso que os viajantes que adentraram o sertão paranaense utilizaram o termo caipira para designar as populações que aí viviam.

Esse modo de vida teria sido resultado da adaptação pela qual passou o português em meio à fronteira-sertão, tendo que assimilar as características nômades e aventureiras dos indígenas. Por esse motivo, Sérgio Buarque de Holanda (1975, p. VII) apontou o avanço dessa fronteira caipira como um movimento que não resultou em uma efetiva ocupação do espaço interior da colônia portuguesa.

Vemos, portanto, que caboclo e caipira são termos correlatos, sobretudo para os que eram oriundos dos centros urbanos da costa atlântica que não compartilhavam desta cultura e a consideravam como rústica e atrasada.

\section{Miradas positivas: os sertanejos em prol da causa nacional}

Ao adentrar a fronteira-sertão, os viajantes se deparavam com outra temporalidade distante de seus referenciais civilizatórios. Demarcar esse distanciamento era um recurso utilizado por eles para indicar sua condição de agente civilizador que estaria fomentando o progresso. Em nome de tão importante dever patriótico, era necessário abster-se das 
comodidades da vida urbana e de sua própria vida privada. Ao relatar a missão confiada ao tenente e engenheiro José Joaquim Firmino para alcançar a tão almejada foz do rio Iguaçu, ponto de contato direto com os argentinos, onde seria instalada uma Colônia Militar, Brito atentou para uma demarcação entre uma centralidade baseada no Rio de Janeiro e uma periferia localizada na fronteira-sertão:

A empresa é hercúlea - diziam - Firmino jamais se embrenha, principalmente em uma região da ordem do Oeste paranaense que, atravessada pela cordilheira de Maracajú, imaginavam-na cheia de extensos e emaranhados alcantis. $\mathrm{O}$ ataque de feras e outros fatores próprios da natureza de matas seculares que o explorador teria que percorrer previam o fracasso!

Firmino não entibiou.

Partiu.

[...] esqueceu das elegantes e atraentes ruas do Rio de Janeiro, para se lembrar somente do compromisso assumido, acrescendo uma circunstância que o devia tê-lo detraído: era noivo. Entretanto tal não aconteceu! (BRITO, 2005, pp. 44-45).

O Rio de Janeiro descrito por Brito foi associado aos novos tempos republicanos e tomado como uma centralidade para se contrapor à barbárie da fronteira-sertão. Para valorizar o trabalho patriótico da expedição que deveria fundar a colônia militar e levar a modernidade para este espaço, o viajante assinalou que os sertanejos que aí viviam ainda estavam presos à outra temporalidade que deveria ser superada: "para os habitantes da foz do Iguaçu, o país ainda estava no regime Imperial” (BRITO, 2005, p. 87).

Após cruzar a boca do sertão do Chagú ${ }^{13}$, a caminho da foz do Iguaçu, tomando Curitiba como uma centralidade, Nascimento também

\footnotetext{
13 Atualmente corresponde a uma área pertencente ao município paranaense de Nova Laranjeiras.
} 
realizou esse tipo de demarcação. A floresta densa representava um contraste em relação à capital paranaense e suas benesses modernizadoras:

Ao descer a noite sobre aquelle ermo, entrevendo pelas folhagens estrellas piscando no alto de um azul nítido, junto a mim o sussurro monotono de um ribeirão impetuoso a precipitar-se pela canhada, invadiu-me uma saudade infinita do lar, dos meus tenros filhinhos; depois um desejo imenso de perambular áquella hora pelas livrarias da rua 15 , toda illuminada com os seus grandes focos electricos. E como tivesse amansado nos dentes um naco de carne secca e salgada, lembrei-me com certa gulodice do Agostinho, do Stock, do Dolsky e do Giovanni, para uma ceia de bohemio, e dos virtuosos vinhos do Queiroz e do Bentim.

Se as pernas voassem como o pensamento, certo que naquella noite eu teria destruído as 100 léguas que me afastavam da capital paranaense. Depois, passava em tropel como um desfilar de recordações gratas toda essa geração de intellectuaes que tantos louros tem recolhido para nossa terra, nas lettras como nas artes, nos estudos de nossa historia como na descripção e propaganda das nossas bellezas, e com a qual tenho o gáudio de conviver intimamente.

E de um sonho de saudades, passam meus olhos a ferir a treva que se extende pelos recônditos da espessa floresta (NASCIMENTO, 1903, p. 88).

A rua XV de novembro - anteriormente chamada rua da Imperatriz - conforme a própria nomenclatura indica, faz alusão à proclamação da República e simbolizava os anseios de uma elite curitibana republicana que queria se desvencilhar do seu recente passado imperial. Nascimento demarcou de maneira constante esse choque de temporalidades. Enquanto cruzava o meio-oeste paranaense, registrou que estava em meio a um universo sertanejo onde as pessoas regiam o seu tempo pelo sol e pela lua. Tratava-se de uma antítese em relação à visão de mundo do viajante atrelada à racionalidade capitalista-ocidental, onde o tempo era controlado de maneira sistemática pelo relógio. Por 
esse motivo, recorria ao calendário gregoriano para não se sentir deslocado em meio à temporalidade paralela da fronteira-sertão:

DIA 22.-Em marcha para os campos de Palmas.

Nota: Éramos obrigados a tomar diariamente a data do mez, o dia da semana e o espaço percorrido, porque em viagens tão cheias de peripecias, affeito á vida sertaneja, como que até se perde a noção do tempo e do espaço.

$[\ldots]$

Um mez de viagem. O que irá pela Capital? pelo Brazil? por todo o orbe? Segregado da movimentação quotidiana e das novidades dos centros populosos, em pleno sertão, o homem até esquece os dias da semana [...] (NASCIMENTO, 1903, p. 25 e 77).

Para Arthur Franco ${ }^{14}$, desconhecedor do longo caminho terrestre que cortava o sertão entre Curitiba e a foz do Iguaçu, o elo com a civilização era pela via do rio Paraná. Era por esse meio que existia contato com os centros "civilizados" de Buenos Aires e das cidades costeiras do Brasil. Adentrar o que ele chamava de "interior do sertão" (FRANCO, 1973, p. 31) - para cumprir com a sua tarefa de mensurar as terras dos empresários argentinos - representava outra temporalidade. Quanto mais o adentrava, mais distante estaria do mundo civilizado. Regressar para as margens do Paraná representava um alívio justamente porque teria contato com jornais e revistas, símbolos de modernidade que eram inacessíveis em meio à fronteira-sertão:

14 O paranaense Arthur Martins Franco (1876-1979) foi engenheiro a serviço do governo do Paraná na altura em que empreendeu suas expedições para a fronteira. Entre 1904 e 1914, em duas expedições distintas, comandou atividades de demarcação e medição de terras para exploração da erva-mate no oeste do Paraná. A primeira viagem, realizada por via marítima até Buenos Aires, tendo em seguida subido o rio Paraná até o sertão paranaense, tinha por objetivo a demarcação de terras para os empresários argentinos Domingo Barthe, Pedro Núñez e Lázaro Gibaja. Franco ainda foi deputado estadual, deputado federal, professor da Universidade do Paraná e presidente do Instituto Histórico (NÍCOLAS, 1984). 
Depois de três dias de descanso [...] iniciamos a nossa viagem de regresso, a 30 de janeiro, para as barrancas do Paraná [...]. Nos primeiros dias (num dos primeiros) de fevereiro chegamos ao nosso antigo acampamento "12 de Outubro"15. D. Jayme Pagés aguardava ali a nossa chegada, que foi festejada à "champagne". Foi com avidez que nos deitamos à leitura de jornais e revistas, que há tanto tempo não víamos. Encontramos já iniciada a esplanada para as construções dos futuros edifícios, no Porto, à margem do rio [...] (FRANCO, 1973, p. 42).

Figura 2: Porto 12 de Outubro

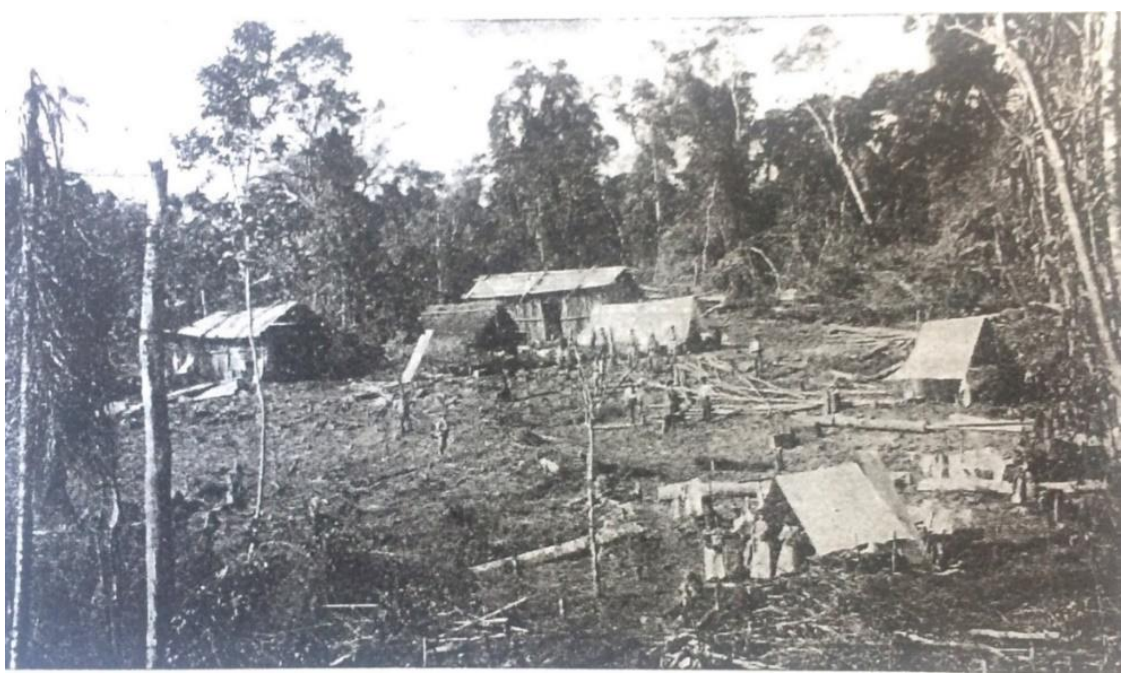

Fonte: (FRANCO, 1973)

No entanto, a fronteira-sertão deveria ser domesticada pelo Estado brasileiro, sobretudo numa área fronteiriça com a Argentina. Silveira Netto $^{16}$, outro viajante que não percorreu a penosa travessia

15 Atualmente é uma área pertencente ao município de Pato Bragado/PR.

16 Manuel Azevedo da Silveira Netto (1872-1942) empreendeu uma expedição para a fronteira-sertão do Paraná em 1905. Tendo tomado o caminho marítimo e fluvial, o seu objetivo foi a instalação da Mesa de Rendas do Ministério da Fazenda em Foz do Iguaçu. Ela também foi motivada pela repercussão do relato de Domingos Nascimento, 
terrestre - mas que descreveu o caminho com detalhes através de citações a outros autores - assinalou o quanto "a audácia e a ciência da engenharia militar brasileira cortaram veredas para a ligação telegráfica da fronteira e prosseguimento do caminho estratégico" (SILVEIRA NETTO, 1995, p. 17).

O telégrafo, a ciência e a engenharia militar eram representantes da modernidade tão presente no discurso positivista dos republicanos brasileiros. Seria com essa estrutura que os agentes estatais avançariam as fronteiras da nação brasileira.

Essa missão civilizadora, entretanto, não seria possível sem o suporte dos próprios sertanejos. Ao mesmo tempo em que eram alvo de projeções que os colocavam como cidadãos de segunda classe, eram eles os verdadeiros conhecedores dos caminhos, verdadeiros vaqueanos ${ }^{17}$ que guiavam os forasteiros pela fronteira-sertão. Eram, portanto, personagens centrais dentro desse movimento de expansão da fronteira. Nascimento, quando passou pelos campos de Palmas -tradicional rota de passagem e invernada das tropas que conduziam muares da região sul até Sorocaba, no interior paulista- apontou para a necessidade de contar com um sertanejo-tropeiro como guia por essas paragens desconhecidas:

É do centro dos campos de Palmas que bem se pode avaliar o quanto de annos as numerosas cavalgadas têm calcado o solo pedregoso dessa região, e o quanto de perigoso existe para o viajante que se arrisque a atravessalos sem um guia.

Carreiros profundos e innumeros trilham se cruzando por toda parte, de maneira que um desvio qualquer, por um minimo descuido,

onde o autor teceu pesadas críticas ao regime fiscal e aduaneiro existente na fronteira (MYSKIW, 2009, p. 69).

17 Término utilizado para designar uma pessoa conhecedora dos caminhos de uma região a que habitualmente pertence (COMISSOLI, 2018, pp. 131-132). 
resultaria uma perdida por essas paragens, algumas vezes ermas de habitações. É que os trilhos se confundem, ora se justapondo, ora se sobrepondo, ora ainda se contornando de tal sorte, que o cavalleiro, aturdido, desorientado, pode lançar-se por um desvio, indo bater em sentido opposto ao rumo que pretendia seguir (NASCIMENTO, 1903, p. 36).

Após cruzar os campos de Palmas e alcançar a boca do sertão do Chagú, o caminho de Nascimento tomou o rumo oeste para "penetrar as densas selvas do Iguassu" (NASCIMENTO, 1903, p. 35). Se para ele, a área de campo aberto era de difícil locomoção, a mata densa que margeava o rio Iguaçu era um ambiente ainda mais inóspito, era onde o perigo era uma companhia constante durante a viagem. No momento em que a expedição abria caminho pela selva com o uso do machete instrumento de corte utilizado pelos argentinos - o viajante relatou um momento onde sofreu uma queda repentina em meio a um precipício. Sendo assim, assinalou a importância do sertanejo vaqueano que o ajudou a se safar desta situação:

[...] mais 3 léguas até o arroio Peroba. É um trecho este dos mais difficeis de passar; porquanto, tendo seguido uma turma adeante de nós a abrir caminho, de novo sobre elle descera o tacuaral a um leve sopro de aragem, formando um tunnel immenso, ininterrupto.

Com o meu facão em punho a cortar matto para passar, fui nesse dia pela vez primeira experimentar o effeito de uma descida aos trambolhões por despenhadeiro abaixo com Cavallo e tudo.

Quando dei accordo de mim, jazíamos os dois, eu e o meu fiel animal, amigavelmente deitados um ao lado do outro, ambos de pernas para o ar, debaixo de um enorme e intenso tramado impossivel de romper.

O meu bagageiro, homem pratico e dedicado, salvounos da situação, abrindo ás pressas uma passagem (NASCIMENTO, 1903, p. 87).

$\mathrm{Na}$ medida em que foi penetrando essa região de mata densa, registrou o quanto o vaqueano habituado ao ambiente do sertão era uma 
figura importante dentro da conjuntura do processo civilizador e do movimento de fronteira. Não foi mera coincidência o fato de ter tecido descrições positivas sobre os tropeiros que eram bastante atreladas ao contexto do Romantismo. O fato ocorreu quando armou acampamento, logo após o episódio onde foi salvo por um dos seus guias: "De minha cama contemplo um bello quadro de vida sertaneja: lá no fundo da matta, para outro lado, faisca a enorme fogueira dos tropeiros abrindo pela ramaria extenso clarão" (NASCIMENTO, 1903, p. 88).

A luz emanada pelos tropeiros era como um feixe de civilização em meio à escuridão do sertão. Era parte do movimento irrefreável da fronteira brasileira que teria que fazer frente à presença argentina. Esses momentos colocam os sertanejos como parte essencial nesse processo.

No caso da expedição da qual Brito era parte, ela também contava com seus guias sertanejos que eram a linha de frente do batalhão liderado pelo tenente Firmino. $\mathrm{Na}$ medida em que o grupo realizou o trajeto entre Guarapuava e a foz do Iguaçu, o viajante relatou que o seu superior foi nomeando os acidentes geográficos que foi encontroando pelo caminho. Conforme aponta Carter (1987, p. 137), o ato de nomear os lugares pelos quais o viajante percorre, serve como um recurso eficiente para legitimar poder e controle político sobre a região descrita. Tratava-se, portanto, de uma estratégia de legitimar o avanço da fronteira e a ocupação do espaço por parte do então recém-proclamado Estado republicano brasileiro. Não foi por acaso que alguns nomes de rios como Tiradentes e Castro Alves remetiam diretamente ao novo regime (BRITO, 2005, p. 52). Entretanto, o que mais chama a atenção nesse percurso é que um dos picadores pertencentes ao grupo da linha de 
frente, responsável por abrir picadas em meio à mata, foi nomeado no relato: tratava-se do sertanejo Salvador do Mato. De uma maneira indireta, Brito conferiu autoridade ao verdadeiro descobridor do caminho que conduziu a expedição ao seu destino final que era a foz do Iguaçu:

Firmino e os que estavam próximos se precipitaram para a frente, com o fim de verificar o que afirmava o Salvador do Mato.

Constava a existência da picada, conforme anunciará o picador, os homens da turma que estavam presentes, experimentaram tanta emoção, tão forte, tão viva que não puderam falar, nem atenderem o tenente que lhes falara, no momento! Não era para menos! Tantos meses internados, passando a mesma vida sem mutação de painel, sem atrativos, insípida, sem notícias, onde as únicas vozes que ouviam era [...] o brasmir das feras que se anunciavam na quebrada da serra (BRITO, 2005, pp. 53-54).

Ainda que, de maneira constante, Brito tenha legitimado a autoridade do tenente Firmino como o "descobridor" da foz do Iguaçu, ele também acabou por apontar que foi Salvador do Mato o responsável por descobrir o caminho rumo à fronteira. $O$ fato foi tão importante para a expedição, cuja moral estava baixa em meio a uma penosa e longa viagem pela fronteira-sertão, que o viajante acabou por pormenorizar os detalhes do acontecimento, dando inclusive os créditos ao sertanejo picador e registrando a euforia da tropa que ignorou por um momento a própria autoridade do tenente.

Os picadores eram também parte da linha de frente da expedição de Silveira Netto, o qual não deixou de registrar o fato quando empreendeu uma jornada até as cataratas do Iguaçu:

Munidos de farnel e preparos de pouso, cavalgamos os nossos animais, na sede da antiga colônia do Iguaçu, e partimos por ínvios 
atalhos florestais adentro, dorso curvado para evitar o galho pendente ou o espinheiro agressivo da picada.

Á frente um camarada, facão em punho, abria o matagal, facilitandonos a passagem. Atravessamos cautelosamente o rio S. João ${ }^{18}$, que por ali passa, galgamos a barranca oposta e abrimos vereda para a frente, pregozando a nova emoção que nos aguardava (SILVEIRA NETTO, 1995, p. 81).

O espaço compreendido entre a boca do sertão do Chagú e a foz do Iguaçu era a região mais crítica no que tocava as intempéries enfrentadas pelas expedições brasileiras. Silveira Netto e Arthur Franco não se arriscaram por esse caminho, era esta uma rota utilizada exclusivamente pelos militares. O tenente José Cândido da Silva Muricy ${ }^{19}$ foi um dos que enfrentou tal odisseia: “Por vezes se desanima n'esse interminavel sertão de 40 legoas, em que não se leva em conta tantos e tão fortes ondulações” (MURICY, 1999, p. 59).

Nascimento e Brito sinalizaram que essa empreitada não seria possível sem o suporte dos sertanejos. Apesar de Muricy ter apontado para uma suposta falta de suporte para a sua expedição, quando se aventurou pelas cataratas, o papel do vaqueano foi essencial em sua tarefa de medição da profundidade do rio. O sertanejo tinha um papel fundamental nas questões científicas levantadas pelos viajantes. Sem o seu auxílio e "audácia", não haveria dados a serem enviados ao governo brasileiro:

Quanto á sua profundidade, cremos ser pouca, porque um camarada [...] que acampára comnosco, teve a enorme audacia, de ir com agua

\footnotetext{
18 Afluente do rio Iguaçu.

${ }^{19}$ O Militar paranaense José Cândido da Silva Muricy (1863-1943) empreendeu viagem, por via terrestre, em 1892, como parte de uma expedição que teve por objetivo inspecionar a Colônia Militar do Iguaçu. Os apontamentos de viagem, escritos inicialmente em seu diário, foram publicados mais tarde, em 1896.
} 
até a cintura e o peito, agarrando-se de pedra em pedra, até perto dos saltos Tiradentes, no angulo, sendo obrigado a voltar para não ser arrebatado pelas aguas, que segundo elle diz, têm uma força extraordianaria, que augmenta progressivamente, á proporção que se aproxima da queda (MURICY, 1999, p. 83).

Ainda que os viajantes tenham ressaltado o espaço fronteiriço como obscuro e impenetrável, sobretudo no sentido oeste após Chagú, há que aclarar que tal projeção também consistia num recurso textual para legitimar a conquista da fronteira-sertão. Ressaltar tais atributos daria uma maior credibilidade para o processo civilizador brasileiro que estava em movimento. A localidade de Catanduvas representava um posto avançado dessa fronteira em movimento. Era um pequeno campo aberto que Nascimento enxergava como um enclave de civilização em meio à mata densa. Localizava-se a 115 quilômetros ao oeste de Chagú e consistia em um ponto de apoio entre a recém-fundada Colônia Militar do Iguaçu e a base militar de Guarapuava. Quando passou por essas paragens, o viajante relatou o contato que travou com um guia local, um homem negro chamado Appolinario. Não se tratava, entretanto, de alguém nascido no sertão, nem sempre o sertanejo era nativo deste ambiente. Em alguns casos, poderia ser uma pessoa adaptada a este contexto espacial. Assim como os europeus que se adaptaram à dinâmica de coleta da erva-mate nas margens do Iguaçu, Appolinario era um exmilitar baiano que fixou residência na fronteira-sertão, onde passou a exercer a função de vaqueano das tropas que avançavam para o oeste:

Ah, que bella surpresa! Depois de opprimido pela selva impenitente, o livre ar dos campos e uma habitação para descanço.

Catanduvas não é propriamente um campo na acepção do termo, e sim um descampado de cerca de 1 kilometro de comprimento com 300 metros de largura. 
No meio do rectângulo fica um galpão de madeira, de regular tamanho e onde reside o preto Appolinario, ex-praça do exercito. Lá tem elle a sua plantação de milho e a sua criação de porcos (sancho), em não pequena escala.

É um dos fornecedores de alimentação ás tropas que passam da colonia do Iguassu para a cidade de Guarapuava.

É bahiano e fala como uma preta mina.

[...] serve de guia a algum passageiro, que vindo só, tem receios de atravessar o inhospito e sombrio sertão para sahir nos campos (NASCIMENTO, 1903, pp. 90-91).

Para além da condição de sertanejo-vaqueano, a origem étnica de Appolinario chamou a atenção de Nascimento. Tratava-se de um descendente de escravos mina ${ }^{20}$ que ainda falava um dialeto proveniente do Golfo da Guiné, na África Ocidental. Sua descrição é coerente com a que foi realizada por Nina Rodrigues ${ }^{21}$, que encontrou falantes dessa língua em Salvador ainda no final do século XIX (RODRIGUES, 2010, p. 142-143).

O sertanejo poderia ser tanto alguém que pertencia um grupo que estava há gerações na fronteira-sertão, como poderia ser uma pessoa "aclimatada" por este ambiente. Em relação ao primeiro caso, Nascimento teceu uma minuciosa biografia de um homem chamado Jose Benedicto, descrito como uma pessoa rústica e alegre. Ele prestou serviços como guia para o exército brasileiro em 1852 durante uma

\footnotetext{
20 Tal designação era uma forma genérica de designar os escravos embarcados na Costa da Mina, correspondente a uma região do golfo da Guiné que abrange o litoral dos atuais estados de Gana, Togo, Benim e Nigéria. O mais famoso porto de embarque de escravos foi a feitoria de São Jorge da Mina, em torno da qual se desenvolveu a atual cidade de Elmina, em Gana. Ver: (GESTEIRA, 2011).

21 Médico e antropólogo maranhense que desenvolveu toda a sua atividade intelectual em Salvador/BA. É considerado o fundador da antropologia criminal brasileira e pioneiro nos estudos sobre a cultura negra no país, ainda que sob uma perspectiva baseada no determinismo científico que ainda apontava o negro como uma raça inferior.
} 
expedição que buscava descortinar um caminho terrestre entre o Rio de Janeiro e a fronteira do Mato Grosso, tendo continuado a exercer a sua função de vaqueano até a virada do século XX: "Este velho que lá vive no fundo do sertão, inestimáveis serviços prestara como guia aos exploradores que buscavam a foz do Iguassu e o valle do Chopim [...]" (NASCIMENTO, 1903, p. 80).

Benedicto também participou da Revolução Federalista ${ }^{22}$ ao lado das tropas legalistas. Por esse motivo ganhou a simpatia de Nascimento, a ponto de ter a sua fala registrada, onde conta um episódio de bravura frente à presença de Juca Tigre ${ }^{23}$, líder da facção inimiga:

De uma feita — era pela revolução — os gaúchos de Juca Tigre penetraram em sua casa.

Terminado o infallivel jantar, carregaram-no prisioneiro e, depois de apresentado ao chefe, levaram-no a matar.

Mas, -narra elle com os olhos em fogo e gesto ameaçador- «mas, na occasião de passarem-me a degolla, mostrei-me tão calmo e valente, que a escolta retrocedeu, voltando commigo ao acampamento. Poucos momentos depois Juca Tigre me dissera: «Ias ser morto, porque és um pica pau, mas és um bravo deante da morte: é que a morte tem medo de ti. Vae, José Benedicto em paz.» «E largou-me.»

-Ah, se não fosse a minha presença de espirito, a castelhanada ${ }^{24}$ passava-me a faca, não tinha que ver» (NASCIMENTO, 1903, p. 80).

22 Guerra civil que ocorreu no sul do Brasil, logo após a Proclamação da República, ocasionada pela crise política gerada pelos federalistas, grupo opositor a Júlio de Castilhos, governador do Rio Grande do Sul. Seu objetivo era conquistar maior autonomia e descentralizar o poder da então recém-proclamada República Brasileira. Durou de fevereiro de 1893 a agosto de 1895, sendo vencida pelos seguidores de Júlio de Castilhos. O conflito atingiu o Rio Grande do Sul, Santa Catarina e Paraná e teve como uma de suas consequências, o exílio de refugiados que passaram para o lado argentino da fronteira.

${ }^{23}$ Seu nome verdadeiro era José Serafim de Castilhos, foi um dos principais líderes da Revolução Federalista.

24 Referência aos voluntários uruguaios que lutaram na Revolução Federalista ao lado dos rebeldes. 
A fronteira-sertão era o cenário de refúgio dos que eram acossados pelos desdobramentos da Revolução Federalista. Internar-se pelo sertão o mais oeste possível era a melhor alternativa para quem buscava alguma paz. Esse movimento de pessoas estava alheio aos limites que estavam sendo projetados por Brasil e Argentina dentro deste espaço litigioso. Os vaqueanos Pedro Gonçalves e Luiz Machado eram gaúchos que se deslocaram para Campo Erê, dentro da região em disputa pelos dois países, e depois para San Pedro, território argentino, devido à incidência de conflitos no Rio Grande do Sul que acabaram se alastrando pelo oeste catarinense e paranaense.

[...] demoramos no sitio de Pedro Gonçalves, rio grandense, ha muitos annos residente em Campo-Eré e que também acossado pelo pavor da guerra civil veio parar em S. Pedro.

De todos os brazileiros residentes é este o que por seu gênio affavel e espirito emprehendedor melhor tem adquirido meios de subsistência: tem boa criação de gado e porcos, e possue duas tropas ao serviço de transporte de herva matte.

Outro a quem a felicidade também tem bafejado, pois vive sem privações, é Luiz Machado, o bom patrício que nos conduziu até Campo-Eré.

Pedro Gonçalves é vaqueano de toda essa zona e me informou que indios vindos dos sertões que ficam entre a costa do Uruguay e o Capitinga, entre o Chapecó e o Pepiry-Guassú, noticiam a existencia de um campo a sueste do Campo-Eré, desconhecido pelos moradores dessa grande zona.

Esse campo é chamado da Vacca Branca, e ja alguns exploradores de hervaes têm notado grandes queimadas para aquellas bandas.

Os mappas dão essa região por desconhecida (NASCIMENTO, 1903, p. 160).

No caso destes sertanejos-gaúchos -reconhecidos por Nascimento como seus patrícios- eram eles também responsáveis pelo avanço da fronteira brasileira. $O$ viajante tomou nota da informação repassada por Pedro Gonçalves, a qual, por sua vez, foi repassada pelos 
indígenas da região, no sentido de registrar o avanço da ocupação de uma zona apontada como desconhecida pelos mapas oficiais.

$\mathrm{Na}$ conclusão do seu relato, Nascimento enfatizou a importância do avanço da fronteira oeste não só para fazer frente à presença argentina, mas também para estabelecer a tão almejada conexão terrestreferroviária entre o Rio de Janeiro e o Mato Grosso ${ }^{25}$, região fronteiriça estratégica e ponto de contato entre a bacia platina e a bacia amazônica. Ainda que ele tenha ressaltado o papel dos engenheiros no que tocava os estudos de implementação dessa rota, não deixou de conferir legitimidade à atuação dos sertanejos que retificou os estudos anteriores relacionados ao traçado da futura rota:

[...] na época que [...] illustres engenheiros [...] preconisavam o traçado pelo valle deste rio, nada se sabia das condições topographicas daquella zona, que posteriores explorações, feitas por profissionaes (Odebrecht, Gengembre) e por sertanejos, patentearam como pouco favoráveis para construcção da importante via projectada (NASCIMENTO, 1903, p. 195).

$\mathrm{Na}$ medida em que o sertanejo era visto como um agente importante dentro da dinâmica desta fronteira móvel, o olhar dos viajantes resultava ser positivo, sobretudo quando era detentor de alguma posse, o que o diferenciava do sertanejo-caboclo que vivia exclusivamente de subsistência. Esse olhar positivo foi registrado por Nascimento quando estava a caminho dos Campos de Palmas:

${ }^{25}$ Existiu um debate dentro do círculo dos engenheiros militares a respeito do traçado dessa rota. A primeira opção seria através de Catalão/GO. A outra era por Guarapuava/PR. Nascimento, defensor dos interesses do Paraná, apoiou a segunda posição (NASCIMENTO, 1903, p. 67). 
E também devo desde já deixar aqui patente que em todos os pousos, quer de ida quer de volta, por toda essa longa travessia de 380 léguas, as nossas despesas cifraram-se apenas em alugueis de muares, gratificações aos tropeiros e um que outro comestível para os logares desabitados onde tínhamos de fazer uso das barracas.

Isto em pleno sertão. Pelas fazendas, pelas choupanas, pelos acampamentos de hervateiros, nacionaes ou extrangeiros, os seus moradores rivalizaram na fidalguia do trato, sem ter querido acceitar da comitiva um ceitil. É grato, pois, ao escriptor destas paginas assignalar o seu penhor, tão captivo que ficou á população do interior do Paraná, nimiamente distincta e hospitaleira (NASCIMENTO, 1903, p. 25).

Estando na região de Palmas, ao realizar pouso na fazenda de São Christovão, não deixou de salientar a importância do "hospitaleiro povo do sertão" (NASCIMENTO, 1903, p. 34). A imagem do sertão pobre e atrasado desaparece ao salientar " [...] tão rica e prospera [...] zona paranaense que não se encontra [...] miséria pelos lares, ainda os mais modestos" (NASCIMENTO, 1903, p. 48).

A dicotomização entre a capital paranaense e o sertão acabou por dar lugar a uma comparação entre os sertanejos e a população caiçara do litoral paranaense. O motivo era bastante simples: Nascimento era nascido na litorânea Guaraqueçaba, próximo ao porto de Paranaguá. Embora tenha vivido a maior parte de sua vida em Curitiba, não deixou de evocar suas memórias e impressões sobre as gentes da costa, as quais teve bastante contato na infância. Na comparação com o sertanejo, apontou que o interiorano levava vantagem:

[...] O matuto do interior não se descuida: tem na porcada que ceva, nas aves que procrêa e no gado que reproduz a segurança de que não lhe faltará nunca a si e ao seu hospede um prato confortável.

Não tanto assim as populações modestas da marinha: Faltando o peixe, se o mar é estuoso, e a farinha, se a domina a saporema-eis a miséria dentro do lar, porque nem todos têm o bananal e os 
tubérculos da terra á porta, quando as enchurradas lhes invadem as searas (NASCIMENTO, 1903, pp. 48-49).

Estando em Guarapuava, a capital paranaense voltou a ser parâmetro de comparação. No entanto, desta vez, eram os interioranos que eram os civilizados. Nascimento se encantou com uma parada militar realizada pelos alunos do Instituto Becker ${ }^{26}$. Para ele, seriam esses meninos os verdadeiros representantes da nacionalidade brasileira em meio à fronteira-sertão, o que contrastava com a mocidade curitibana, que, segundo ele, estava desvirtuada dos ideais pátrios e de civilização:

Manobravam no campo com tal correcção á voz de cominando, partiam ao trote, ao galope com tal segurança, que contemplando-os me ufanei cheio de justos orgulhos por esses futuros defensores da Republica e da integridade de nossa Patria. É que esses levam para a mocidade o cunho da destreza physica e da sanidade moral.

Que tristeza tamanha contemplar agora a meninada travessa da nossa Capital, nos torneios das ruas, nas amotinadas dos circos de touros e de cavallinhos, ou jogando pedradas nas vidraças dos nossos palacetes, quando não fazendo experiencias de mão certeira nos focos de luz electrica ou na cabeça dos transeuntes (NASCIMENTO, 1903, p. 68).

Os alunos do instituto receberam um olhar positivo porque seguiam as diretrizes militares que eram consideradas como parâmetros de civilização para Nascimento. Quando direcionou o seu olhar para o caipira paranaense e suas crendices, ainda que tenha nutrido certa simpatia pelo outro, o distanciamento foi demarcado. Nesse sentido, relatou a crença dessas populações em torno do monge João Maria ${ }^{27}$ :

\footnotetext{
${ }^{26}$ Fundado em 1901, com subsídio do governo do Paraná, pelo professor argentino Juan Rodrigues Becker y Silva.

${ }^{27}$ Nascimento faz menção ao segundo dos três monges que realizaram suas atividades messiânicas pelo sul do Brasil. Em 1912, o terceiro monge liderou um levante dos sertanejos contra a presença de empresas estrangeiras, as quais, apoiadas pelo governo
} 
Eis-me em presença, pela vez primeira, de uma fonte milagrosa. Os tropeiros não passam por aquelle ponto sem levantar a aba do chapéo, em signal de veneração á pequena ermida, ou sem descer do animal para beber a agua benefica, abençoada pelo milagroso João Maria.

Este cenobita, um velho rijo e secco, anda ha 40 annos perambulando por aquellas paragens: Fura o sertão até a Lagoa Vermelha; de lá corta os campos de Palmas; vae ao Tibagy; vence as florestas e as montanhas dos Agudos; interna-se no Paranapanema; faz por lá os seus milagres, as suas predicas, as suas orações; dá os seus bons conselhos, e retorna derivando para as margens do Iguassu, Jangada e não sei por onde mais. Andarilho de primeira, erra por montes e valles, andrajoso e esquálido, com um bastão apenas por arma. Não ha insecto que lhe morda as carnes, nem feras que lhe môam os ossos. Quando passa pelos arredores-não penetra nunca as povoações-é um nunca acabar de povo ao seu encalço, pedindo bênçãos e curas.

E João Maria, muito nobre na sua missão consoladora dos afflictos e bem feitora da humanidade, aconselha paz e amor, applica beberagens e cataplasmas aos enfermos, sem receber dadiva alguma, sem acceitar um catre ao menos onde repousar.

Alimenta-se apenas com verduras.

Feita a cura ou a predica aos que o procuram, raspa-se, desapparecendo no fundo das mattas, sem se lhe saber o rumo.

Quando é menos esperado, reapparece, cada vez mais consolado da sua penosa missão sobre a terra.

Descrente por princípios e temperamento, procurei esmiuçar melhor a sua vida e o seu fim. Para as populações do interior esse individuo é um santo, porque até o presente, dizem os seus fieis, ainda não deu motivos de uma queixa sequer [...] (NASCIMENTO, 1903, p. 28).

O contato travado com os sertanejos seguidores do monge não implicou em um olhar negativo. Muito pelo contrário, Nascimento até mesmo esqueceu por um momento de sua crença irrefreável nos valores ilustrados e manifestou certo encanto pela "barbárie". O momento simbólico onde isso se tornou mais latente foi quando resolveu imitar a prática religiosa dos caipiras ao tomar a água santa do monge:

brasileiro, expulsaram os sertanejos de suas terras, o que acabou desembocando nos conflitos da Guerra do Contestado. 
[...] João Maria para o caipira é um santo, porque as suas curas são certeiras, os seus conselhos beneficos.

O logar onde descança está abençoado. Deste modo fica explicada a existência da «Agua Santa», no caminho que vai; do Jangada aos campos de Palmas.

Pois, meus senhores, a veneração é communicativa. Depois da narrativa dos feitos indeleveis desse pobre mortal como eu, que não tinha uma enxerga tão nova como o meu poncho-pala, nem uns pés tão rápidos e firmes como os do meu bucefalo, mas que possuia $\mathrm{o}$ prestigio e a confiança de toda uma população ordeira e grata aos seus beneficios_-eu me senti pequenino, vasio de glorias e de ideaes; e incendido pelo mal-estar da miragem por péssimos caminhos, como um crente cheio de fé, ardente, indigno, perdido o bom humor, desci do burrico, dobrei o dorso e de joelhos-metti a bocca dentro da fonte milagrosa... morto de sède!

Foi uma resurreição... (NASCIMENTO, 1903, p. 29).

Nascimento foi ainda mais além, ao registrar o quanto os seus efeitos eram realmente verdadeiros, conferindo assim uma legitimidade à crença sertaneja, a qual seria tão legítima quanto o próprio catolicismo oficial.

\section{Miradas negativas: os "hunos" do sertão como um entrave para o avanço da fronteira}

Sendo um legalista convicto, o relato de Nascimento é permeado pela sua visão a respeito dos acontecimentos relativos à Revolução Federalista, ocorrida alguns anos antes da sua expedição, cujos desdobramentos ainda se faziam sentir na fronteira-sertão. O caso dos refugiados que foram para o exílio no lado argentino é um exemplo desta conjuntura. Influenciado por este contexto, emergiu em sua narrativa um olhar negativo a respeito do sertanejo-gaúcho. Para ele, o espírito da 
ordem e da civilização ainda não teria penetrado a sua índole moral. Assim relatou a presença gaúcha na região de Bella Vista de Palmas ${ }^{28}$.

Eu dizia que Bella Vista é o actual refugio dos que passam a fronteira ${ }^{29}$; e de facto: por todo o município cruzam emigrantes com famílias e tropas em demanda de novos lares, porque se queixam de que no Passo Fundo e Palmeira as questiunculas de partidos se acham tão aferradas, que já não é possível viver ali com certa calma de espirito. É que, infelizmente, naquella zona da bella terra gaúcha, ainda não penetrou o espirito de ordem entre os seus habitantes, não experimentados sufficientemente com a licção das luctas enganosas e estereis que forraram de lucto o coração da patria, por longos annos.

Não me supponham exagerado nesta affirmativa, pois que basta mencionar que o sertão do rio do Peixe, de nosso lado, está sendo povoado por mais de 200 pessoas ali refugiadas.

Como prova, o exemplo da Irany, da Frigorifica, cujos arredores constituem uma grande colonia rio-grandense que occupa aquelle valle, suppondo as terras devolutas (NASCIMENTO, 1903, p. 42).

Da mesma maneira que demarcou uma centralidade em Curitiba em oposição a uma periferia localizada na fronteira-sertão, Nascimento reconfigurou essa dicotomia ao transitar por este espaço. Os centros urbanos e os postos avançados do exército eram considerados como focos de civilização. Era o caso das localidades de Guarapuava e Catanduvas. Por esse motivo, era positiva a visão sobre os habitantes dessas paragens. O mesmo não ocorria quando relatava os habitantes da zona rural, nesse caso, ele assumia as vestes de civilizado, emanando assim uma visão negativa acerca dos sertanejos, os quais não teriam apresso pelo bom gosto da estética do mundo civilizado:

28 Corresponde ao atual município paranaense de Clevelândia, cuja nomenclatura homenageia o presidente Cleveland, justamente por ter arbitrado o litígio fronteiriço a favor do Brasil.

${ }^{29}$ Nascimento faz referência à antiga fronteira entre o Paraná e o Rio Grande do Sul. Nesse período o atual oeste de Santa Catarina era reivindicado pelo estado do Paraná. Santa Catarina venceu a disputa litigiosa em 1916. 
Havia uma boa quinzena que fazíamos pouso em modestas habitações; porque, seja dito em honra á verdade, fora dos povoados, nossos campeiros e sertanejos, com muito boas excepções, de tudo cuidam menos de conforto em suas moradias. Feitas as suas moradas sem arte, rara é a casa de campo ou de sertão onde se sinta certo resguardo contra as intempéries e certo gosto artístico que deve fazer parte integrante da vida emocional por aquelles desertos e por aquellas solidões onde frequentemente passam homens de espirito culto e observador.

[...] A vida de sociedade ainda não está bem compreendida por estas paragens (NASCIMENTO, 1903, pp. 59-60).

Sendo assim, o habitante do campo teria que ser incorporado pela civilização. Os postos avançados dos militares teriam justamente essa função "redentora". Nesse sentido, a localidade de Mallet foi outro exemplo elencado por Nascimento.

O telégrafo, símbolo da modernidade para a época, aí já se fazia presente. A missão dos militares era justamente a de convocar os sertanejos da região para que eles fossem incorporados a este novo centro urbano. Outra questão era relativa à nacionalização desses "matutos" -atribuição pejorativa que configurava num olhar negativo por parte do viajante- que observavam o hasteamento da bandeira brasileira com desconfiança, como se fosse uma situação distante da que viviam até a chegada dos forasteiros. A própria nomenclatura da cidade, a qual homenageava o Marechal Emílio Mallet ${ }^{30}$, lhes causava estranheza. Provavelmente ninguém ali teria ouvido falar naquele homem. O que pouco importava aos militares, já que, considerando os pressupostos teóricos de Carter, a nomeação dos lugares consistia em um esforço de

30 Militar franco-brasileiro que atuou em várias intervenções brasileiras no Prata, como a Batalha do Passo Rosário, a Guerra contra Rosas em Buenos Aires e a Guerra da Tríplice Aliança. 
legitimar o seu próprio projeto ideológico e não o que pensava a gente sertaneja:

[...] numa posição admirável de belleza, está assentada a Villa Mallet [...] Bem no centro da Villa está edificado o belíssimo chalet da estação telegraphica.

O encarregado dessa estação, Valério Pedro, moço bastante intelligente e activo, tem feito grandes melhoramentos no edifício e se empenhado com feliz êxito em chamar os habitantes dos arredores para aquelle povoado, distribuindo-Ihes as casas construídas pela commissão militar.

O elegante chalet achava-se todo empavezado, sobresahindo no tope de alto mastro o pavilhão nacional.

Contemplar por alguns momentos a nossa bandeira desfraldada aos ventos por logares remotos, no meio de uma população em sua maioria composta de matutos, é sentir sobre a alma um jorro consolador, misto de orgulho e civismo pátrios e gravar no espirito uma phrase de esperança de melhores dias áquella pobre gente, cujos destinos e conhecimentos do mundo são os horizontes que apenas os seus olhos contemplam da porta da cabana (NASCIMENTO, 1903, p. 79).

A visão de Silveira Netto era ainda mais enfática e com menos nuances se comparado ao olhar de Nascimento. Quando esteve na foz do Iguaçu, a sua preocupação não residia apenas sobre o avanço argentino sobre um território pretendido como nacional, os "brasileiros erradios" que viviam de maneira autônoma, sem a interferência do Estado, eram motivo de pesadas críticas de sua parte. $\mathrm{O}$ viajante citou as palavras de Sebastião Paraná, ardoroso republicano paranaense, para descrever a região antes do estabelecimento da colônia: "[...] o louro branco e o cedro [...] atraíram por alguns anos os estrangeiros e nacionais erradios que em busca de erva-mate clandestinamente enriqueciam, antes da fundação da colônia, com exportá-las para os portos argentinos [...]" (SILVEIRA NETTO, 1995, p. 52). Esses “erradios” eram os sertanejos que viviam ali antes da chegada efetiva dos representantes do Estado 
brasileiro. O relato do viajante acabou por revelar que essas pessoas possuíam autonomia para negociar livremente com os ervateiros argentinos. O que nos dá um panorama sobre como funcionava esta borderland no período anterior à chegada dos agentes estatais.

Tal conjuntura nos dá margem para pensar a respeito do tipo ideal de cidadão que, segundo Silveira Netto, deveria ocupar a fronteira. Em sua visão, os sertanejos não corresponderiam a esse tipo ideal. O que diferia da posição de Nascimento que advogava pela "civilização" dessas pessoas. Nesse sentido, manifestou um claro distanciamento em relação ao outro. O seu modo de vida e suas práticas de abrir roçados em meio à mata os tornavam responsáveis pela devastação das florestas. A referência é latente quando assinala que "o machado é o Atila incansável desse império vegetal" (SILVEIRA NETTO, 1995, p. 55). Nesse caso, tratava-se do machado que era empregado pelo habitante do sertão, que num sentido simbólico, referenciando as Invasões Bárbaras sobre o Império Romano durante o século $\mathrm{V}$, era visto como um huno dos tempos modernos, uma ameaça à civilização brasileira que necessitava se afirmar na fronteira:

[...] chegou o dia [...] de ouvir-se naquelas quebradas um eco compassado, perseverante, tenaz... é o machado que fende as árvores. Movem-no os braços brônzeos, os músculos de aço do nosso sertanejo, gente insensível à fome, à fadiga, bem como à beleza e à opulência daquelas paragens.

Meses depois ergue-se no céu o clarão rubro cor de sangue da queimada. Num turbilhão de fogo e de fumo os enormes troncos, os cadáveres da floresta, se estorcem estrepitosamente e se reduzem a cinzas.

Dez anos mais tarde convertem-se aqueles encantos da natureza em cerrados estéreis, em samambaias improdutivas.

Um cabedal imenso armazenado nas fibras daquelas árvores e nos princípios azotados daquelas terras consumiu-se em chamas e se evaporou nos ares. 
Atrás do machado e do fogo fica o deserto (SILVEIRA NETTO, 1995, pp. 55-56).

Segundo a descrição acima, o sertanejo seria incapaz de compreender as belezas naturais da nação. Apesar de classificá-lo como "nosso sertanejo", existia um claro distanciamento entre o civilizado, letrado, capaz de promover descrições românticas sobre o espaço, e o bárbaro que apenas pensava em explorar e saquear as riquezas pertencentes à nação.

A “domesticação" do sertanejo na fronteira somente poderia darse pela ação do Estado brasileiro, o qual ditaria as regras após o seu estabelecimento neste espaço. No entanto, ao mesmo tempo em que Silveira Netto elencava possíveis soluções para controlar essa população, o seu relato revela toda uma dinâmica onde essas pessoas possuíam autonomia para comercializar madeira e erva mate. Como uma autêntica borderland, não importava se o intercâmbio comercial se dava além dos rios Iguaçu e Paraná. Para essa população, a fronteira política não tinha significado algum.

Outra maneira de demarcar distanciamento e ressaltar o lado negativo do sertanejo era através de seus costumes alimentares. Em meio à fronteira-sertão, Nascimento salientou o quanto seu paladar estava “estragado pela alimentação a carne secca” (NASCIMENTO, 1903, p. 102). Ao chegar às margens do rio Floriano Peixoto, já nas proximidades da foz do Iguaçu, travou encontro com Francisco Guilherme dos Santos, um ex-militar pernambucano que fixou residência na fronteira após a Revolução Federalista. Nascimento o descreveu como um homem já aclimatado ao sertão. Para além de ressaltar a sua condição de "mulato", 
descreveu também as suas práticas culinárias. Francisco preparou um "Caboré", uma variação da chipa paraguaia. Mas o que mais chamou a sua atenção foi o fato desta comida ser preparada "com a celebre graxa que por ali se vende”, uma espécie de tempero preparado com restos de carne bovina, que em sua visão era "de um gosto repugnante e rijo de arrancar dentes" (NASCIMENTO, 1903, p. 101).

Uma visão parecida foi emitida por Arthur Franco: "Havia [...] ali [...] uma grande lata de «gracha de vaca» que era empregada no tempero do «Jupará», já aberta e cujo cheiro, naquele recinto fechado, se tornava insuportável”. Ele ressaltou ainda o quanto um membro de expedição chamado Aristides "dormia dentro do «rancho», suportando, valentemente, o nauseabundo cheiro da graxa" (FRANCO, 1973, pp. 3233).

O Jupará era uma comida típica daquela região fronteiriça, depreciada pelos viajantes, mas que era consumida por toda a população daquela zona, pouco importando a fronteira política que estava sendo idealizada pelos forasteiros.

Arthur Franco demarcou que o milho utilizado era o "pindocado", nomenclatura que ele atribuiu ser utilizada pelo "nosso caboclo” (FRANCO, 1973, p. 33), configurando assim um distanciamento em relação ao sertanejo que utilizava palavras de um dialeto próprio que era distinto do que era falado de acordo com a norma culta da língua portuguesa. 
Figura 3: 1 Distribuição de comida em Lopey.

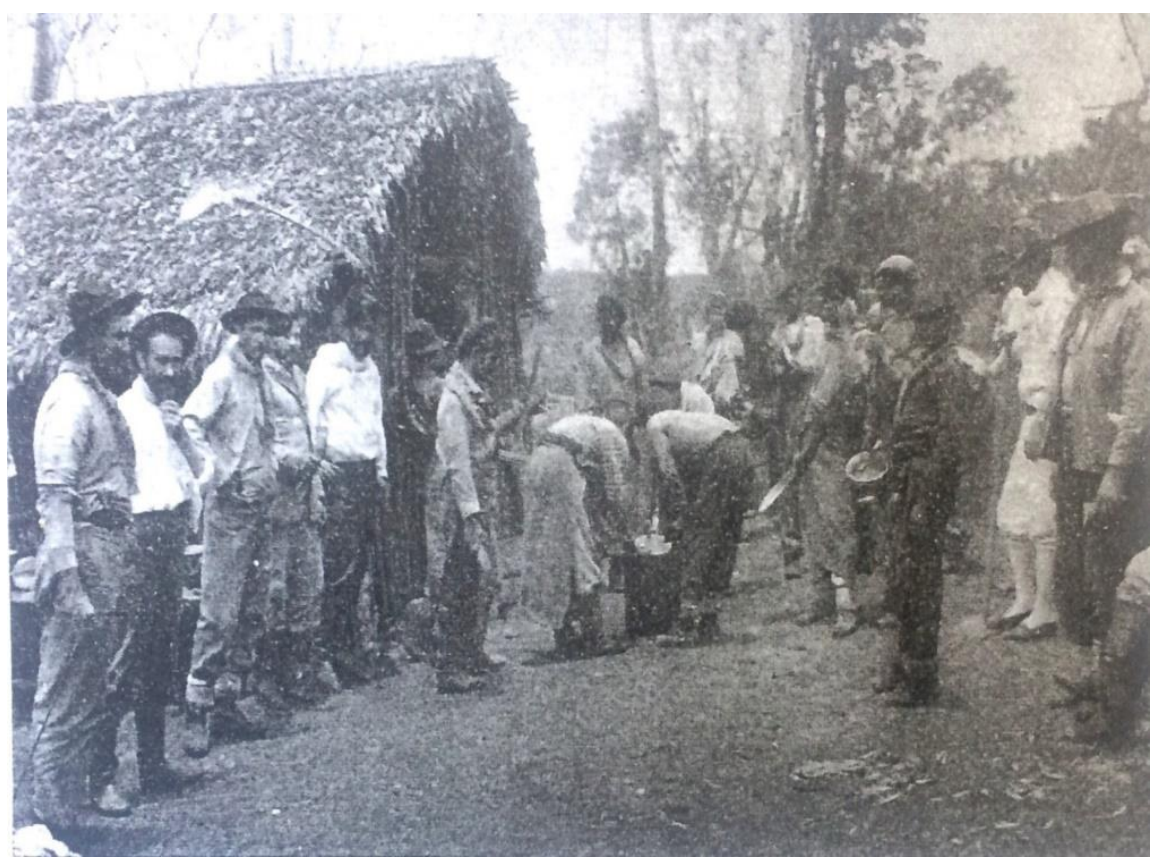

Fonte: (FRANCO, 1973)

Ainda que a expressão "nosso caboclo" apontasse o sertanejo como parte integrante da nação brasileira, era notório o distanciamento emanado pelos viajantes, sobretudo, no que tocava as expressões relacionadas à fala do outro. Nascimento definiu o modo de se expressar do sertanejo como uma "linguagem rústica mas muito pittoresca" (NASCIMENTO, 1903, p. 80).

As referenciações acrescidas de aspas atribuídas às palavras sertanejas denotam o quanto existia essa demarcação. Por outro lado, ainda que essas fontes oficiais estejam carregadas pelo olhar dos agentes estatais, uma análise mais apurada nos permite debruçar sobre a questão do falar e do dialeto do sertanejo. Nesse sentido, o linguista Ênio José 
Toniolo (2008-2009, p. 314) empreendeu um estudo acerca de outro relato de Muricy intitulado Viagem ao país dos jesuitas, resultado de uma expedição empreendida pelo norte paranaense, cujo objetivo era encontrar as ruínas da antiga localidade espanhola de Villa Rica del Espíritu Santo. Segundo o referido autor, embora se baseando em uma fonte oficial, foi possível abordar "vestígios de oralidade, sempre presentes nos textos escritos, apesar de policiados pela norma culta e pela finalidade com que eram redigidos".

Embora tenha destacado algumas palavras do vocabulário sertanejo, sobretudo, no que tocava a flora ${ }^{31}$, o relato de Muricy sobre a fronteira com a Argentina não é tão detalhado quanto o que escreveu sobre o norte do Paraná. No entanto, o seu relato a respeito do sertanejo norte-paranaense elucida uma manifestação de alteridade para com o outro: "Na sua linguagem, curiosa e pitoresca, além dos vícios comuns à parte ignorante da nossa população [...] o o é por vezes substituído pelo e, i, u: possuir (pessuí, pissuí), conversa (cumbersa), em que o v é também substituído pelo b” (MURICY, 1975, p. 55).

Segundo a socióloga Maria Alice Setúbal (2005, p. 103), o dialeto caipira é influenciado pela língua tupi-guarani, onde não existem os sons para as letras d, f, l, v, z. Temos como exemplo a pronúncia do "lh" que é trocada pelo "i". Essa maneira de falar persiste até nossos dias, mas também foi registrada por José Maria de Brito em 1889 na fronteira com a Argentina. Quando o sertanejo Salvador do Mato encontrou um caminho aberto pelos ervateiros argentinos, o viajante assim registrou a sua fala: “óia uma picada aqui" (BRITO, 2005, p. 53).

${ }^{31}$ Como por exemplo: nhapindás e gurupiás (MURICY, 1999, p. 50). 
Ainda que Brito tenha qualificado o dialeto sertanejo como uma forma de "bárbarismo" 32 , de uma maneira constante, foi elencando a nomenclatura sertaneja ao lado das palavras provenientes da norma considerada culta da língua portuguesa e também através de notas de rodapé. Sendo assim, o seu relato não deixa de ser uma importante fonte de registro da oralidade presente na fronteira-sertão do oeste paranaense naquele período: "O couro de anta é conhecido como «camocica», entre os sertanejos. Este vocábulo [...] é barbarismo do caboclo paranaense. [...] Há duas classes de veado: o conhecido pelo nome «pardo» e outra menor que o sertanejo denomina «Capororóca»" (BRITO, 2005, p. 66).

Silveira Netto, estando na fronteira no auge do verão, comparou o clima daquele espaço às "terras do norte" brasileiro. Ao mesmo tempo, lamentava a proliferação de mosquitos por aquela zona. Registrou ainda que o referido inseto era denominado pelos sertanejos como "Barigui" (SILVEIRA NETTO, 1995, p. 47). Arthur Franco, no mesmo sentido, registrou a fala sertaneja no momento da abertura de uma nova picada pelo sertão: “[...] a picada foi aberta através de largo trecho de um chapadão revestido de um bambusal espinhoso a que a peonada dava o nome de «jatevoca»" (FRANCO, 1973, p. 41).

Quanto mais os viajantes brasileiros se aproximavam da foz do Iguaçu, ficava difícil estabelecer uma fronteira entre o que era o "nosso" e o que era o "deles" (argentinos). O sertanejo de Porto União da Vitória, no centro-sul do Paraná, não era o mesmo que habitava a

\footnotetext{
32 Mais tarde, em 1920, o escritor paulista Amadeu Amaral buscou legitimar esse modo de falar através do seu compêndio intitulado Dialeto Caipira. Sendo um membro da Academia Brasileira de Letras, buscou seguir um método de coleta de expressões que respeitasse as normas da filologia moderna, dando assim credibilidade científica ao seu trabalho (FERREIRA, 2019, p. 45).
} 
fronteira com a Argentina. Neste espaço, era difícil atribuir uma nacionalidade de fato às pessoas do lugar. Muitas vezes, o dialeto e as expressões utilizadas não respeitavam a fronteira política que era projetada pelos Estados brasileiro e argentino.

Era esta borderland, portanto, um espaço fértil para as projeções emanadas pelos forasteiros. Nascimento, ainda que tenha manifestado olhares positivos a respeito do sertanejo, quando se aproximou da foz do Iguaçu, mesmo estando ainda em território considerado brasileiro, demarcou uma fronteira imaginária entre o que era "nosso" e o que era “deles". Nesse caso, o habitante do sertão brasileiro, através de uma mirada negativa, era "de cútis negra e indianos, alguns bisonhos, outros maltrapilhos". Enquanto que o interiorano argentino era visto por ele como "uma raça bonita e intelligente, trajando roupas decentes, gorro vermelho á cabeça, faixa vermelha cintando os quadris, um longo chiripá bordado descendo até os pés, resguardando as pantalonas dos espinhos e da lama. [...] Entre-rianos e correntinos” (NASCIMENTO, 1903, p. 94).

O uso do chiripá denunciava que a descrição não fazia referência aos "ilustrados" de Buenos Aires. Tratava-se da tradicional indumentária gaucha, típica do habitante da pampa argentina, cuja influência alcançou também Misiones e as províncias adjacentes. O próprio viajante brasileiro apontou que se tratavam de entrerrianos e correntinos. Era, portanto, uma referência em relação ao outro interno argentino, a qual, por sua vez, servia de parâmetro de comparação para com o outro interno brasileiro. Ao considerar o contexto brasileiro da mestiçagem entre brancos, negros e indígenas, Nascimento considerava que os nacionais eram inferiores em relação ao outro estrangeiro. No entanto, 
ele não levou em consideração que o debate intectual a respeito da raça também era presente dentro do círculo intelectual argentino ${ }^{33}$.

\section{Comentários finais}

Salvador do Mato, Appolinario, José Benedicto, Pedro Gonçaves, Luiz Machado e Francisco Guilherme dos Santos foram os sertanejos citados nominalmente pelos viajantes brasileiros. A proposta de analisarmos os relatos através de uma ótica pós-colonial nos permitiu que a voz deste outro fosse emergida dos relatos, ainda que a sua escrita fosse carregada pelo olhar oficial destes agentes ligados ao Estado.

Ao analisarmos o avanço sobre o sertão do Brasil Meridional como uma experiência histórica de fronteira móvel, pudemos notar os olhares ambíguos dos viajantes a respeito dos habitantes com os quais eles travaram contato ao longo de seus caminhos. Esse olhar vai mudando conforme vai se dando a movimentação das próprias expedições. $\mathrm{Na}$ medida em que os viajantes se deslocaram mais para o oeste, eles adentraram a uma borderland, um espaço transnacional onde o sentido da fronteira foi completamente ressignificado, já que ali existiu um choque com outro movimento de fronteira oriundo de Buenos Aires. Mesmo após 1895, momento onde ocorreu a demarcação formal dos limites entre Brasil e Argentina, o projeto nacional de "domesticação",

\footnotetext{
33 Alberdi e Sarmiento, assim como grande parte da intelectualidade argentina, foram partidários de um "branqueamento" da população através do fomento da imigração europeia. Contudo, ademais do impacto em cidades como Buenos Aires, Santa Fé e Mendoza, a Argentina permanecia com sua população basicamente constituída por mestiços (LACOSTE, 2003, p. 120).
} 
tanto do espaço sertanejo, como de suas gentes, ainda teria largos anos pela frente.

O pensamento social brasileiro como um todo ainda não enxerga o avanço sobre a fronteira-sertão como uma experiência histórica de fronteira móvel. Nosso recorte teve a peculiaridade de analisar um espaço transnacional. Entretanto, as possiblidades de estudo estão abertas para inúmeras outras realidades sertanejas de norte a sul do Brasil, assim como em outras realidades transnacionais como a fronteira com as Guianas, o espaço amazônico, além de outros recortes dentro da própria bacia platina.

\section{Referências}

ABRAMOVAY, Ricardo. Transformações na vida camponesa: $O$ Sudoeste paranaense. (Dissertação de Mestrado em Ciência Política). FFLCH/USP, São Paulo, 1981.

ADELMAN, Jeremy; ARON, Stephen. From borderlands to borders: empires, nation-states, and the peoples in between in North American. The American Historical Review. Vol. 104, No. 3, pp. 814-841. jun.1999.

ALBERDI, Juan Bautista. Bases y puntos de partida para la organización política de la República Argentina. Buenos Aires, (s/d).

ANTONIO FILHO, Fadel David. Sobre a palavra "sertão": origens, significados e usos no Brasil (do ponto de vista da ciência geográfica). Ciência Geográfica - Bauru, pp. 84-87, 2011.

BOLTON, Herbert Eugene. The Spanish Borderlands: a chronicle of old Florida and the Southwest. New Haven: Yale University Press, 1921. 
CANDIDO, Antonio. Os parceiros do Rio Bonito. São Paulo: Livraria Duas Cidades, 2001.

CARTER, Paul. The road to Botany Bay. An exploration of landscape and history. Minneapolis: University of Minnesota Press, 1987.

COMISSOLI, Adriano. Bombeiros, espias e vaqueanos: agentes da comunicação política no sul da América portuguesa (Rio Grande de São Pedro, sécs. XVIII-XIX. Revista de Indias, Madri, LXXVIII/272, pp. 113-146, 2018.

DARONCO, Leandro Jorge. Afro-brasileiros nas "margens" do Uruguai. In: FINOKIET, Bedati Aparecida (Org). Fronteiras e Interculturalidade. Tubarão: Copiart, 2018, pp. 261-286.

FERREIRA, Aurélio Buarque de Holanda. Novo dicionário da língua portuguesa. Segunda edição. Rio de Janeiro: Nova Fronteira, 1986.

FERREIRA, Elton Bruno. As representações da cultura caipira nos escritos de Cornélio Pires: tradição, identidade, política e cotidiano (1910-1932). Tese de doutorado em História, PUC-SP, 2019.

GESTEIRA, Vinicius Lins. Relato e interpretação da justiça na Costa da Mina durante o século XVII: mudança ou permanência na prática do juramento de ingerir fetiche? 2011. Disponível em: $<$ http://www.costadamina.ufba.br/ ARQ/Textos/LINS\%20Beber $\% 20$ fetiche.pdf $>$ Acesso em 30 jan. 2020.

LACOSTE, Pablo. Estanislao Zeballos y la política exterior Argentina con Brasil y Chile, Revista Confluencia, Mendoza, ano 1, n. 2, pp. 107-128, 2003.

LIMA, Nísia Trindade. Um sertão chamado Brasil - Intelectuais, sertanejos e imaginação social. Rio de Janeiro: Tese apresentada ao Instituto Universitário de Pesquisas do Rio de Janeiro - Universidade Cândido Mendes, 1997.

LIMERICK, Patricia. The legacy of Conquest: the unbroken past of American West. New York: W. W. Norton \& Company, 1987. 
LEMOS, Marilene Aparecida. Entre espaços, sujeitos e línguas: a produção da fronteira em Dionísio Cerqueira-SC, Barracão-PR (Brasil) e Bernardo de Irigoyen (Misiones, Argentina) nos relatos de viagens. Tese de doutorado - Instituto de Estudos da Linguagem da UNICAMP, Campinas, 2019.

LORENZETTI, Fernanda Lorandi. Terra de Lírios Bravos e Homens Fortes: Notas acerca das atribuições de identidade ao Paraná por Domingos Nascimento (1895-1914). Dissertação de mestrado Universidade Federal da Grande Dourados, 2009.

MÄDER, Maria Elisa Noronha de Sá. Civilização e Barbárie: a representação da nação nos textos de Sarmiento e do Visconde do Uruguai. Tese (Doutorado) - Instituto de Ciências Humanas e FilosofiaUFF, Niterói, 2006.

MAIA, Doralice Sátyro. A Ferrovia nas cidades Bocas de Sertão: Alterações na Morfologia Urbana e no Território Brasileiro. I Seminário Internacional Brasil no século XIX. Vitória: Sociedade Brasileira de Estudos do Oitocentos. 2014. Disponível em: < https://www.seo.org.br/images/Anais/Arthur/Doralice $\% 20$ Styro $\% 20$ Maia.pdf $>$ Acesso em 28 jan.2020.

METCALF, Alida. Family and Frontier in Colonial Brazil: Santana de Parnaíba, 1580-1822. Berkeley, Los Angeles, Londres: University of California Press, 1992.

MYSKIW, Antonio Marcos. A Fronteira como Destino de Viagem: A Colônia Militar de Foz do Iguaçu (1888/1907). Tese de Doutorado Instituto de Ciências Humanas e Filosofia-UFF, Niterói, 2009.

MORAES, Antonio Carlos Robert. Território e História no Brasil. São Paulo: Hucitec, 2002.

.O sertão: um "outro" geográfico. Terra Brasilis - Revista de história de pensamento geográfico no Brasil, p. 11-23, 2002-2003.

NíCOLAS, Maria. 130 Anos de Vida Parlamentar Paranaense 18541984. Curitiba: Setor de Editoração e Publicações da Coordenadoria de Estudos e Promoções Especiais, 1984. 
RODRIGUES, Raymundo Nina. Os Africanos no Brasil. Rio de Janeiro: Centro Edelstein de Pesquisas Sociais, 2010. Disponível em: < https://static.scielo.org/scielobooks/mmtct/pdf/rodrigues-

9788579820106.pdf> Acesso em 23 mai. 2020.

ROMERO, Sílvio. Estudos sobre a poesia popular do Brazil (18791880). Rio de Janeiro: Typ. Lammert \& C., 1888.

SARMIENTO, Domingo Faustino. Facundo: Civilización y barbarie, Buenos Aires: Centro Editor de Cultura, 2007.

SCHNEIDER, Alberto Luiz. Capítulos de História Intelectual: Racismos, identidades e alteridades na reflexão sobre o Brasil. São Paulo: Alameda, 2019.

TURNER, Frederick Jackson, $\mathrm{O}$ significado da fronteira na História Americana. In: KNAUSS, Paulo (org.). Oeste Americano. Rio de Janeiro: Editora da UFF, 2004, pp. 23-54.

\section{Fontes}

BRITO, José Maria de. Descoberta de Foz do Iguaçu e a fundação da Colônia Militar. Foz do Iguaçu: Travessa dos Editores, 2005.

FRANCO, Arthur Martins. Recordações de viagens ao Alto Paraná. Curitiba: Imprensa da Universidade Federal do Paraná, 1973.

MURICY, José Cândido da Silva, Viagem ao país dos jesuítas. Curitiba: Imprensa Oficial do Estado do Paraná, 1975.

Á Foz do Iguassú - Ligeira Descripção de uma Viagem Feita de Guarapuáva á Colonia da Foz do Iguassú em Novembro de 1892. In: DENIPOTI, Cláudio; BERBERI, Elizabete. Relatos de Viagem à Guaíra e Foz do Iguaçu (1870-1920). Curitiba: Aos Quatro Ventos. 1999, pp. 45-86. 
NASCIMENTO, Domingos Virgílio do. Pela Fronteira. Curitiba: Typografia da Republica, 1903.

SILVEIRA NETTTO, Manuel Azevedo da. Do Guairá aos Saltos do Iguaçu. Curitiba: Fundação Cultural, 1995. 